\title{
Effects of Metal and Metalloid Contamination on Microbial Diversity and Activity in Agricultural Soils
}

\author{
Sherlyn C. Tipayno, Puneet S. Chauhan, Sungman Woo, Bohee Hong, Keewoong Park', \\ Jongbae Chung ${ }^{2}$, and Tongmin $\mathrm{Sa}^{*}$ \\ Department of Agricultural Chemistry, Chungbuk National University, Cheongju, Chungbuk, \\ 361-763, Republic of Korea \\ ${ }^{1}$ Bio-Evaluation Center, KRIBB, Cheongwon 363-883, Republic of Korea \\ ${ }^{2}$ Division of Life and Environmental Science, Daegu University, Gyeongsan 712-714, Republic of Korea
}

\begin{abstract}
The continuous increase in the production of metals and their subsequent release into the environment has lead to increased concentration of these elements in agricultural soils. Because microbes are involved in almost every chemical transformations taking place in the soil, considerable attention has been given to assessing their responses to metal contaminants. Short-term and long-term exposures to toxic metals have been shown to reduce microbial diversity, biomass and activities in the soil. Several studies show that microbial parameters like basal respiration, metabolic quotient, and enzymatic activities, including those of oxidoreductases and those involved in the cycle of $\mathrm{C}, \mathrm{N}, \mathrm{P}$ and other elements, exhibit sensitivity to soil metal concentrations. These have been therefore, regarded as good indices for assessing the impact of metal contaminants to the soil. Metal contamination has also been extensively shown to decrease species diversity and cause shifts in microbial community structure. Biochemical and molecular techniques that are currently being employed to detect these changes are continuously challenged by several limiting factors, although showing some degree of sensitivity and efficiency. Variations and inconsistencies in the responses of bioindicators to metal stress in the soil can also be explained by differences in bioavailability of the metal to the microorganisms. This, in tum, is influenced by soil characteristics such as CEC, $\mathrm{pH}$, soil particles and other factors. Therefore, aside from selecting the appropriate techniques to better understand microbial responses to metals, it is also important to understand the prevalent environmental conditions that interplay to bring about observed changes in any given soil parameter.
\end{abstract}

Key words: Metals, Metalloid, Microbial diversity, Microbial activity, Agricultural soils

\section{Introduction}

The capacity of an agricultural area to sustain its productivity relies heavily on the quality of the soil. The soil is a complex medium of minerals, organic solids, aqueous and gaseous components and plays host to a dynamic array of chemical and biological processes essential to the cycle of elements on earth (Alloway, 1995; Oliveira and Pampulha, 2006). By its nature alone, the soil is readily susceptible to influences from physico-chemical factors, biological factors and extraneous factors, such as pollutants. The continuous

\footnotetext{
Received : January 20. 2011 Accepted : February 22. 2011

*Corresponding author : Phone: +82432612561

E-mail: tomsa@chungbuk.ac.kr
}

increase in the production of metals and their subsequent release into the environment has lead to increased concentration of these elements in the soil. Great concern about the presence of these contaminants in the soil is due to their manifold toxicity, which is not only seen in their influence on physico-chemical conditions, but also on the loss of soil microbial diversity and functions leading to reduced soil quality, not to undermine the toxicity posed to plants, animals and humans.

The main metal elements that are known to be toxic pollutants are: cadmium $(\mathrm{Cd})$, chromium $(\mathrm{Cr})$, copper $(\mathrm{Cu})$, mercury $(\mathrm{Hg})$, nickel $(\mathrm{Ni})$, lead $(\mathrm{Pb})$, and zinc (Zn). In addition, the metalloid arsenic (As), has also gained notoriety due to its high occurrence in the environment and toxicity to humans. These elements 
normally occur at very low concentrations in the soil and plants, and some have known biological roles thus, are also referred to as micronutrients (Lacatusu et al., 2008). Examples are $\mathrm{Co}, \mathrm{Cr}, \mathrm{Cu}, \mathrm{Mn}, \mathrm{Mo}$ and $\mathrm{Zn}$, which are essential in small but critical concentrations for normal healthy growth of organisms but are toxic at high concentrations (Alloway, 1995). Metals such as silver (Ag), aluminum (Al), arsenic (As), cadmium $(\mathrm{Cd})$, gold $(\mathrm{Au})$, lead $(\mathrm{Pb})$ and mercury $(\mathrm{Hg})$, do not have any biological functions and are potentially toxic even in low concentrations (Bruins et al., 2000). When present in higher, potentially toxic concentrations, these elements are often given the term heavy metals.

\section{Metal and Metalloid Contamination of Agricultural Soils}

Sources of metals in the soil may be from natural processes, such as weathering of parent rocks and pedogenesis, making them ubiquitous in soil parent material. However, anthropogenic activities have greatly increased their concentration in the soil and environment (and in many cases) beyond allowable threshold limits. The major anthropogenic source of contamination in the soil are related to industrialization and agricultural activities, which includes mining and smelting, waste disposal, waste incineration, traffic emission, urban effluents, fertilizer and long-term wastewater application in agricultural lands (Qishlaqi et al., 2008). These elements do not decay with time. Furthermore, only very low concentrations of these are lost from leaching and plant uptake, allowing them to accumulate slowly in the soil profile over long periods of time (Nicholson, et al., 2003). This can have long term effects on the quality of agricultural soils, in addition to their toxicity to plants, microbial processes in the soil, animals that inhabit or graze on the land and humans whose diet depends on agricultural products. The common metals and metalloids that affect agricultural soils are discussed in the following section.

The magnitude of the effect of metals and metalloid toxicity can be seen in the arsenic pollution of the groundwater in Bangladesh, where over 35 million people have been affected. It was estimated that as high as $10 \mathrm{~kg} \mathrm{ha}^{-1} \mathrm{yr}^{-1}$ is cycled through irrigated water and deposited on the soil surface, where about $83 \mathrm{mg} \mathrm{As} \mathrm{kg}^{-1}$ accumulates (Islam et al., 2006). Arsenite is broadly toxic, binding to sulfhydryl groups, impairing the function of proteins. Metallo-organic forms of As may be much more bioavailable than inorganic forms; however, organic-bound arsenic is excreted by most species and does not appear to be highly toxic.

Cadmium is a rare metal with no known biological function. In the soil, the level is normally low to very low at 0.1-0.5 mg kg${ }^{-1}$ (Baker and Tracy, 2008). In agricultural soils, the concentration rarely goes beyond $10 \mu \mathrm{g} \mathrm{L}^{-1}$ in solutions. However, environmental pollution by this metal has increased in the recent decades due to industrial use. Common sources of soil contamination are from mining and smelting of $\mathrm{Pb}$ and $\mathrm{Zn}$, phosphatic fertilizers, metallurgic industries, waste disposal (e.g. incineration of plastic containers and batteries), sewage sludge application to land, and burning of fossil fuel (Alloway, 1995). Toxicity of Cd has been linked to its strong affinity for cysteine residues and phosphate groups, which could lead to protein denaturation. It is also believed to generate reactive oxygen species and DNA strand breaks (Benavides et al., 2005).

Copper is an essential trace element that is also applied as a fungicide, algaecide, molluscicide and for control of crustaceans. In living organisms, it is required for the functioning of at least 30 redox enzymes and dioxygen carriers, involved in biological processes.

The range of $\mathrm{Cu}$ concentration in soil was reported to be 2 to $100 \mathrm{mg} \mathrm{kg}^{-1}$ with selected average of $20 \mathrm{mg} \mathrm{kg}^{-1}$ (Alloway, 1995). Soils have become contaminated with $\mathrm{Cu}$ by deposition of dust from local sources such as foundries and smelters, as well as from direct application of fungicides and sewage sludge. Total $\mathrm{Cu}$ concentration in the solution of surface soils is normally only 0.01 to $0.6 \mu \mathrm{M}$ because of high affinity for sorption by organic and inorganic colloids (Shorrocks and Alloway, 1985). Copper toxicity has been associated to its redox properties. Extremely reactive hydroxyl radicals can be detrimental to cellular molecules by causing oxidation of proteins and lipids (Yoshida et al., 1993). Copper can also lead to sulfhydryl (e.g. cystein and glutathione) depletion in a reaction that further leads to $\mathrm{H}_{2} \mathrm{O}_{2}$ generation. Alternatively, $\mathrm{Cu}$ can also competitively or nonspecifically bind to $\mathrm{Zn}$ or other metal binding sites in proteins, lipids and nucleic acids (Magnani and Solioz, 2007). This toxic effect has been utilized in agriculture for control of bacterial and fungal diseases.

The major sources of lead in soil are mining and 
smelting activities, manures, sewage sludge usage in agriculture and contamination from vehicle exhaust. Both organic and inorganic forms of $\mathrm{Pb}$ pose serious health risks to all forms of life (Ewers and Schlipköter, 1990). $\mathrm{Pb}$ inhibits the activities of sulfhydryl (-SH) containing enzymes, as well as block their $-\mathrm{COOH}$ groups.

Mercury has no known biological function and is considered as one of the most toxic elements to man and higher animals. The most important sources of agricultural soil contamination have been the use of organic mercurials as seed coat dressing to prevent fungal diseases in seeds and in foliar sprays (Patra and Sharma, 2000). Plant roots tend to provide a barrier against the accumulation of $\mathrm{Hg}$ in plants, such that its availability to plants is relatively low. Mercury exists in three valence states in sediments and water: elemental $\mathrm{Hg}$ $\left(\mathrm{Hg}^{0}\right), \mathrm{Hg}^{+}$, and $\mathrm{Hg}^{2+}$ (Kersten, 1988). The $\mathrm{Hg}^{0}$ is the most available form for most organisms because of its solubility in lipid rich tissues and primary mode of toxic action in living organisms is thought to be the interference of enzyme function and protein synthesis by binding to sulfhydryl or thiol groups.

Zinc, like $\mathrm{Cu}$, is an essential trace element, forming structural component of many metalloenzymes and acts as catalyst for regulating the activity of specific $\mathrm{Zn}$ dependent enzymes involved in metabolism of nucleic acids, proteins, carbohydrates and fatty acids and even photosynthesis (Adhikari and Ayyappan, 2004). Soil contamination by $\mathrm{Zn}$ originates from metalliferous mining activities, agricultural use of sewage sludge and composted materials and the use of agrochemicals such as fertilizers and pesticides.

\section{Effects of Metal and Metalloid Contamination on Soil Microorganisms}

Almost every chemical transformation taking place in soil involves active contributions of soil microorganisms. Microbes greatly influence soil fertility because of their involvement in the geochemical cycle of nutrients (e.g. $\mathrm{C}$ and $\mathrm{N}$ ) and the decomposition of organic matter. Free and symbiotic microbes (e.g. mycorrhizae) increase availability of mineral nutrients, fix N, produce growth promoting compounds (e.g. vitamins and plant hormones), and reduce plant pathogen (Liao and Xie, 2007). Any disturbance imposed on microbial populations and their activities has the potential of upsetting ecological balance in the soil and affecting soil quality and productivity. For this reason, understanding microbial sensitivity to metal contamination in the soil is crucial.

Although there are already a number of studies on the toxicity of metals on microbes, the specific mechanisms by which they interact with soil component to effect such changes on microbial populations and processes remains less understood (Sobolev and Begonia, 2008; Giller et al., 2009). A number of studies have shown that short-term and long-term exposures to toxic metals reduce microbial diversity, biomass and activities in the soil (Vasquez-Murrieta et al., 2006; Kao et al., 2006; Wang et al., 2007a; Wang et al., 2007b; Liao and Xie, 2007). The principal effects of metal toxicities in the soil include reduction in species diversity, microbial biomass, increase in rate of respiration, and changes in microbial community structure (Liao and Xie, 2007; Crowley, 2008). A number of studies have also reported rise in metal tolerant populations in metal polluted soils (Kanazawa and Mori, 1996; Ellis et al., 2003; Almas et al., 2004; Chien et al., 2008).

\section{Effects of Metals on Microbial Biomass}

Soil microbial biomass (SMB) refers to the portion of soil organic matter composed of living microorganisms smaller than the $5-10 \mu^{3}$. It is generally expressed in the milligrams of $\mathrm{C}$ per kilogram of soil $\left(\mathrm{mg} \mathrm{C} \mathrm{kg}^{-1}\right)$ or micrograms of $\mathrm{C}$ per gram of dry weight of soil $(\mu \mathrm{g} \mathrm{C}$ $\left.\mathrm{g}^{-1}\right)$. Less frequently, it is also expressed as $\mathrm{N}$ contained in SMB. Typical biomass $\mathrm{C}$ ranges from 1 to $5 \%$ of soil organic matter. Methods used to estimate the soil microbial biomass include: staining and counting the microbial cells, use of physiological parameters such as ATP, respiration, and heat output; and application of a soil fumigate and measurement. Soil microbial biomass has long been suggested to be a significantly more sensitive indicator of changing soil conditions than the total soil organic matter content (Brookes, 1995; Dai et al., 2004). See table 1 for a summary of recent studies using this index. Soil amended with metal-contaminated sludge has been shown to reduce the biomass $\mathrm{C}$ to organic C ratio by as much as $50 \%$ (Brookes, 1995; Giller et al., 1998), although other results showed more moderate rates of reduction (Dahlin et al., 1997). 
Table 1. Indices for assessing effect of metals on soil microorganism.

\begin{tabular}{|c|c|c|c|}
\hline Index & Description & Toxic effect of metal & Metals Concerned \\
\hline $\begin{array}{l}\text { Soil microbial } \\
\text { biomass }\end{array}$ & $\begin{array}{l}\text { soil OM composed of living } \\
\text { microorganisms smaller than the } \\
5-10 \mathrm{~m}^{3} \text {, generally expressed in } \\
\text { the milligrams of carbon per } \\
\text { kilogram }\left(\mathrm{mg} \mathrm{C} \mathrm{kg}^{-1}\right) \text { of soil or } \\
\text { micrograms of carbon per gram } \\
\left(\mu \mathrm{g} \mathrm{g}^{-1}\right) \text { of dry weight of soil }\end{array}$ & $\begin{array}{l}\text { decrease; negatively } \\
\text { correlation to metal } \\
\text { concentration }\end{array}$ & $\begin{array}{l}\text { As (Ghosh et al., 2004, Edvantoro, } \\
\text { 2003); Cd, Cu, Pb, Zn (Yao et al., } \\
\text { 2003; Yao et al., 2003; Kilzikaya } \\
\text { et al., 2004; Zeng et al., } 2007 \text { Liao } \\
\& \text { Xie, 2007; Wang et al., (2007a) } \\
\text { Zhang et al., 2008a) }\end{array}$ \\
\hline $\begin{array}{l}\text { Basal } \\
\text { Respiration }\end{array}$ & $\begin{array}{l}\text { carbon dioxide evolution from } \\
\text { aerobic catabolic processes/ the } \\
\text { rate of mineralization of native } \\
\text { soil organic carbon }\end{array}$ & $\begin{array}{l}\text { decrease; negatively } \\
\text { correlation to metal } \\
\text { concentration }\end{array}$ & $\begin{array}{l}\text { As (Ghosh et al., 2004); Cd, Cu, } \\
\text { Pb, Zn (Yao et al., 2003 Kilzikaya et } \\
\text { al., 2004; Dai et al., } 2004 \text { Renella et } \\
\text { al., 2005; Zeng et al., } 2007 \text { Liao \& } \\
\text { Xie, 2007; Wang et al., 2007a) }\end{array}$ \\
\hline $\begin{array}{l}\text { Metabolic } \\
\text { Quotient }\end{array}$ & $\begin{array}{l}\mathrm{qCO}_{2} \text {, ratio of basal respiration } \\
\text { to microbial biomass }\end{array}$ & $\begin{array}{l}\text { Increase; positively } \\
\text { correlated to metal } \\
\text { concentration }\end{array}$ & $\begin{array}{l}\text { As (Ghosh et al., 2004); Cd, Cu, } \\
\mathrm{Pb}, \mathrm{Zn} \text { (Yao et al., 2003; Zeng et al., } \\
2007 \text { Liao \& Xie, 2007; Zhang et al., } \\
\text { 2008a) }\end{array}$ \\
\hline
\end{tabular}

Interestingly, metal concentrations in all these studies were below the standard limits in the EC directive for soils in those regions (Commission of the European Communities, 1986). Significant decrease in soil microbial biomass $\mathrm{C}\left(\mathrm{C}_{\text {mic }}\right)$ with increased concentration of $\mathrm{Zn}, \mathrm{Cu}, \mathrm{Pb}$ (Liao et al., 2007; Wang et al., 2007a; Wang et al., 2007b; Kao et al., 2006) and As (Edvantoro et al., 2003; Ghosh et al., 2004) have been documented. Muhammad et al. (2005) reported decrease in both $\mathrm{C}_{\text {mic }}$ and $\mathrm{N}_{\text {mic }}$ at 28 days after $\mathrm{Pb}$ and $\mathrm{Cd}$ introduction in soil. Broos et al. (2007) however, questioned the reliability of using this tool in assessing contaminant effect on soil biological functions in the field, where high spatial and temporal variability is inadequately taken into account. Dai et al. (2004) likewise found significant positive correlation between soil heavy metal and biomass $\mathrm{C}$, and to a lower degree with biomass N. However, the ratio of biomass $\mathrm{C}$ to organic $\mathrm{C}$ did not show any correlation with soil metal contents, while the ratios of biomass $\mathrm{N}$ to total $\mathrm{N}$ were negatively correlated with metal contents.

\section{Effect of Metals on Basal Respiration and Metabolic Quotient}

Basal respiration or carbon dioxide evolution is the major product of aerobic catabolic processes in the $\mathrm{C}$ cycle, and indicates total $\mathrm{C}$ turnover in the soil. It is also referred to as the rate of mineralization of native soil organic $\mathrm{C}$. This is often used to compute for the metabolic quotient $\left(\mathrm{qCO}_{2}\right.$, ratio of basal respiration to microbial biomass), which is inversely proportional to the efficiency by which microbes use indigenous substrates in the soil (Liao and Xie, 2007). A change of $\mathrm{qCO}_{2}$ may indicate separately changes on substrates or in community composition, or in both; or may indicate a change in the physiological status of the community without changes in substrates or community, due to altered maintenance requirements. Basal respiration is a good index of the activity of microflora involved in organic matter decomposition (Anderson, 1982; Liao and Xie, 2007). Loss of soil $\mathrm{C}$ due to metal pollution also has implications to global climate change since the soil is a major C reservoir (Crowley, 2008).

Dai et al. (2004) reported a decrease in C mineralization $\left(\mathrm{CO}_{2}\right.$ production) with increasing metal contamination from pasture soils with long history of metallurgic industry waste input, specifically from $\mathrm{Zn}, \mathrm{Cd}, \mathrm{Pb}$ and $\mathrm{Cu}$. The metabolic quotient, however, was shown to be unaffected in this study. Marked increase in $\mathrm{qCO}_{2}$ with increasing concentrations of extractable, as well as total metal concentrations in $\mathrm{Cu}$ mining wasteland soils was cited by Liao and Xie (2007) as indicative of a shift of energy from growth to maintenance in an ecosystem and changes in soil quality in response to heavy metals (Brookes, 1995). Renella et al. (2005) confirmed this with studies on $\mathrm{Cd}$ contaminated plots, adding that 
Table 2. Effect of metals on soil enzymatic activities.

\begin{tabular}{|c|c|c|c|c|}
\hline Enzyme & Enzyme Function & Effect of Metal & Metal/Metalloid & References \\
\hline Catalase & $\begin{array}{l}\text { convert hydrogen } \\
\text { peroxide to water } \\
\text { and oxygen }\end{array}$ & significant decrease & $\mathrm{Cd}, \mathrm{Pb}, \mathrm{Cu}, \mathrm{Zn}$ & $\begin{array}{l}\text { Khan et al., 2007; } \\
\text { Kizilkaya et al., } 2004\end{array}$ \\
\hline \multirow[t]{2}{*}{ Dehydrogenase } & $\begin{array}{l}\text { oxidize organic } \\
\text { compounds by } \\
\text { transferring protons } \\
\text { and electrons from } \\
\text { substrates to acceptors }\end{array}$ & negative correlation & $\begin{array}{l}\mathrm{As}, \mathrm{Cd}, \mathrm{Cu}, \mathrm{Hg}, \\
\mathrm{Pb}, \mathrm{Zn}\end{array}$ & $\begin{array}{l}\text { Ghosh et al., 2004; } \\
\text { Kizilkaya et al., 2004; } \\
\text { Oliveira and Pampulha, } \\
\text { 2006; Mikanova, } 2006\end{array}$ \\
\hline & & $\begin{array}{l}\text { no significant } \\
\text { correlation }\end{array}$ & $\mathrm{Cd}$ & Zhang et al., (2008a) \\
\hline Beta-glucosidase & $\begin{array}{l}\text { degradation of } \\
\text { cellulose to glucose }\end{array}$ & $\begin{array}{l}\text { significant negative } \\
\text { correlation }\end{array}$ & As & $\begin{array}{l}\text { Bhattacharyya et al., } \\
2008\end{array}$ \\
\hline $\begin{array}{l}\text { Phosphatases } \\
\text { (acid/ alkaline) }\end{array}$ & $\begin{array}{l}\text { hydrolysis of } \\
\text { phosphate esters }\end{array}$ & $\begin{array}{l}\text { significant negative } \\
\text { correlation }\end{array}$ & $\mathrm{As}, \mathrm{Cu}, \mathrm{Zn}$ & $\begin{array}{l}\text { Bhattacharyya et al., } \\
\text { 2008; Wang et al., } \\
(2007 a)\end{array}$ \\
\hline \multirow[t]{2}{*}{ Urease } & $\begin{array}{l}\text { hydrolysis of urea } \\
\text { to } \mathrm{CO}_{2}\end{array}$ & $\begin{array}{l}\text { significant negative } \\
\text { correlation }\end{array}$ & As, $\mathrm{Cd}, \mathrm{Pb}$ & $\begin{array}{l}\text { Bhattacharyya et al., } \\
\text { 2008; Kizilkaya et al., } \\
2004\end{array}$ \\
\hline & & $\begin{array}{l}\text { No significant } \\
\text { correlation }\end{array}$ & $\mathrm{Cu}$ & Kizilkaya et al., 2004 \\
\hline
\end{tabular}

increased $\mathrm{qCO}_{2}$ denotes decrease in metabolic efficiency due to diversion into physiological adaptations for heavy metal tolerance. Insam et al. (1996), however, were not able to make a definite correlation between $\mathrm{qCO}_{2}$ and heavy metals on the soil $\mathrm{C}$ dynamics, citing possible confounding effects of varying soil factors, which seems to explain why some authors reported an increase (Fliessbach et al., 1994; Ortiz and Alcaniz, 1993; Liao and Xie, 2007) and some a decrease of the $\mathrm{qCO}_{2}$ (Baath et al., 1991) with heavy metal contamination. Wardle and Ghani (1995) argued that while $\mathrm{qCO}_{2}$ provides a useful measure of microbial efficiency, it has limitations because it can be insensitive to disturbance and ecosystem development, fails to distinguish between effects of disturbance and stress, and does not decline predictably in response to ecosystem development whenever stress increases along succession gradients. See table 1 for a summary of these studies.

\section{Effect of Metals on Enzyme Activity}

Soil enzymatic activity is a sensitive indicator of metal pollution in soils. Soil enzymatic activity is an indication of the soil's potential to perform basic biochemical processes necessary for maintaining its fertility. Soil enzyme inhibition and its extent depend on the nature and concentration of heavy metals and the enzyme present. Some heavy metals have been reported to stimulate the activity of an enzyme (Dick and Tabatabai, 1983; Zheng et al., 1999), but in most cases of contamination, a negative correlation between soil enzymatic activities and metal levels exists. Metals can reduce enzyme activity by interacting with the enzyme-substrate complex, denaturing the enzyme protein, interacting with the enzyme's active site or by interfering with its synthesis within the cell (Vig et al., 2003). Soil enzymatic activities commonly being measured in assessing metal toxicity to the soil include: dehydrogenase, acid and alkaline phosphatase, urease, catalase, arylsulfatase, and protease activity. The use of microbial enzyme activity as indicator of soil quality have been recommended because of their relationship to soil biology, ease of measurement, rapid response to changes in soil management and high sensitivity to temporary soil changes originating from management and environmental factors (Mikanova, 2006). Responses of some of these enzymes to metals stress are shown in Table 2 . 
Dehydrogenase Dehydrogenases are respiratory chain enzymes that play the major role in the energy production of organisms, oxidizing organic compounds by transferring protons and electrons from substrates to acceptors. Since dehydrogenases are essential components of the enzyme systems of microorganisms, dehydrogenase activity (DHA) can be used as an ideal indicator of biological redox systems and as a measure of microbial activity. Kizilkaya et al. (2004) reported a generally negative correlation between total metal content and DHA, with the trend; $\mathrm{Cu}>\mathrm{Cd}>\mathrm{Co}$. Dehydrogenase activity was found to be a sensitive assay for determining the effect of metals, particularly As, $\mathrm{Hg}$ and $\mathrm{Zn}$, on the physiologically active soil microbial biomass, being reduced by about $80 \%$ and $95 \%$ in two consecutive years, in relation to the control soil samples (Oliveira and Pampulha, 2006). Ghosh et al. (2004) reported a significant inhibition of DHA by the exchangeable and water-soluble arsenic and suggested that inhibition of DHA activity might be due to reduced microbial number and activity, since dehydrogenases are intracellular enzymes. Furthermore, their data showed significant correlation of DHA with basal respiration and substrate induced soil respiration. Inhibition of DHA was also shown to be highest within the first two weeks of soil treatment with $\mathrm{Cd}$ and $\mathrm{Pb}$ (Khan et al., 2007). However, Zhang et al. (2008a) did not find any significant correlation between DHA and Cd contents in wastewater irrigated agricultural soils in China, and Kikilkaya et al. (2004) also failed to establish such correlation with $\mathrm{Pb}$ content in soils. One drawback of using DHA as soil microbial activity index is that it is likewise produced by plant and animal cells.

Catalase The first enzyme that was studied in soils was catalase (hydrogen peroxidase oxidoreductase, EC 1.11.1.6), which functions to detoxify the cell by converting hydrogen peroxide to water and oxygen. This enzyme is seen in all aerobic and most facultative anaerobic bacteria but not in obligate anaerobes. Stępniewska et al. (2009) reported that both $\mathrm{Cr}$ (III) and $\mathrm{Cr}(\mathrm{VI})$ have an ability to reduce soil catalase activity with a dosage of $20 \mathrm{mg} \mathrm{kg}^{-1}$ at contamination levels from $75 \%$ to $92 \%$ for $\mathrm{Cr}(\mathrm{III})$ and $68 \%$ to $76 \%$ for $\mathrm{Cr}(\mathrm{VI})$ in relation to the control. Khan et al. (2007) reported significant decrease in catalase activity (8.8-39.9\%) after $\mathrm{Cd}$ and $\mathrm{Pb}$ application. This negative correlation has been reported also by Kizilkaya et al. (2004) from soils in Turkey contaminated with a mixture of different metals. The drawback for this assay is that plants and animals also produce the enzyme and this interferes with accurate prediction of microbial activity.

Phosphatase Phosphatases catalyze the hydrolysis of phosphate esters. These are enzymes with broad specificity and therefore can act on a number of structurally related substrates at widely varying rates (Alef et al., 1995). Phosphomonoesterases catalyze the hydrolysis of organic phosphomonoester to inorganic phosphate, which can be taken up by plants and are therefore important in the cycle of phosphorus. Both acid and alkaline phosphates are believed to play important roles in plant nutrition. The activities of these enzymes are strongly influenced by $\mathrm{pH}$, temperature, organic matter content, soil moisture and anaerobiosis. Because of this, there are seasonal variations in their activities (Alef at al., 1995). Wang et al. (2007a) reported negative correlation between phosphatase activity and $\mathrm{NH}_{4} \mathrm{NO}_{3}$-extractable and total concentrations of $\mathrm{Cu}$ and $\mathrm{Zn}$. A similar trend was reported for alkaline phosphatase activity under $\mathrm{Zn}$ and $\mathrm{Pb}$ (Khan et al., 2007), and As (Bhattacharya et al., 2008) contaminated soils and with $\mathrm{Ni}$ and $\mathrm{Cd}$ amendment (Renella et al., 2005). Acid phosphatase activity in the affected site was $7.8 \%$ of the activities measured in the reference site, and that of alkaline phosphatase was $91.6 \%$. McGrath et al. (1999) reported that $\mathrm{Cd}$ binding on active sites of alkaline phosphatase inactivated the enzyme and disrupted metabolism. Ironically, its activity was reported to have increased under lower concentrations of $\mathrm{Pb}$ (Zeng et al., 2007) and As (Majer et al., 2002) in contaminated soils, although gradually decreasing when $\mathrm{Pb}$ concentration exceeded $300 \mathrm{mg} \mathrm{kg}^{-1}$.

Urease The enzyme urease (EC 3.5.1.5) catalyzes the hydrolysis of urea to $\mathrm{CO}_{2}$ and $\mathrm{NH}_{3}$, as well as the hydrolysis of hydroxyurea, dihydroxyurea and semicarbazid and is, therefore, related to the cycle of $\mathrm{N}$. Urease is an extracellular enzyme and is tightly bound to soil organic matter and soil minerals. Decrease in urease activity was noted after 15 days of incubation in soils treated with heavy metal-containing sludge (Kakhki et al., 2008). This inversely proportional 
relationship between urease activity and metal concentration has also been recorded by other authors, particularly from soils contaminated by As (Bhattacharyya et al., 2008), $\mathrm{Cd}, \mathrm{Pb}$ and $\mathrm{Zn}$ (Kilzikaya et al., 2004; Liu et al., 2007; Mikanova, 2006). However, in other studies, urease activity was not found to be significantly correlated with microbial biomass and had varying responses to other metals (Alef et al., 1995; Kizılkaya et al., 2004).

B-glucosidase $ß$-glucosidase is an enzyme essential for the degradation of cellulose to glucose. It catalyzes the hydrolysis of glucosides to glucose and is required by organisms (fungi, bacteria, and termites) that degrade cellulose. Kuperman and Carreiro (1997) reported depressed B-glucosidase activity in heavy-metal-contaminated sites. B-glucosidase activity in the pushout site was only $3.3 \%$ compared to the reference control site. Other authors have reported similar decrease in the enzyme activity under increased levels of metal contaminations (Eivazi and Tabatabai, 1990; MartínezIñigo et al., 2009).

\section{Effect of Metal Contamination on Microbial Diversity}

Environmental stress caused by toxic metals generally decreases the diversity and activity of soil microbial populations, and upsets the ecological balance of population interactions within the community. Deleterious effects usually come with interaction and inactivation with enzymes and inhibition of metabolic processes (Wang et al., 2010).

Studying the effects of metals on microbial diversity is difficult because of methodological limitations and lack of taxonomic knowledge. Torsvik et al. (1998) estimated that in $1 \mathrm{~g}$ of soil there are about 4000 different bacterial "genomic units" based on DNA-DNA reassociation. Although a number of techniques for studying soil diversity have been introduced, their efficiency and reliability is challenged by several limiting factors. One of this is spatial heterogeneity. Microbial communities exist on such a small scale, that possibly 1 to $5 \mathrm{~g}$ of soil as sample may favor detection of dominant populations only (Grundmann and Gourbiere, 1999). Furthermore, the soil is also heterogeneous with many microhabitats. Another limitation is the inability to culture soil microorganisms. It has been suggested that at least $99 \%$ of bacteria observed under a microscope are not cultured by common laboratory techniques (Borneman and Triplett, 1997; Giller et al., 1998; Pace, 1997; Torsvik et al., 1998) although it is not known if the $1 \%$ that can be cultured is representative of the bacterial population (Kirk et al., 2004). This may actually represent the ecologically relevant portion of the microbial community (Hattori et al., 1997; Ellis et al., 2003). However, it is also likely that the $99 \%$ may be genetically and phenotypically different from the $1 \%$, and therefore only minority of the population is represented using culture techniques. For this reason various molecular techniques have been developed including fatty acid analysis and a number of DNA- and RNA-based methods. These techniques have also their limitations. The more common methods for studying soil microbial diversity are presented in the following sections. Methods to measure microbial diversity in soil can be categorized into two groups: biochemical-based techniques and molecular-based techniques.

\section{Effects of Metals on Micnobial Diversity based on Biochemical-based Techniques}

\section{Plate counts and culture-dependent techniques}

Culture-dependent techniques are fast, inexpensive and can provide information on the active, heterotrophic component of the population. Limitations include the difficulty in dislodging bacteria or spores from soil particles or biofilms, growth medium selections (Tabacchioni et al., 2000), growth conditions (temperature, $\mathrm{pH}$ and light), the inability to culture a large number of bacterial and fungal species with current techniques and the potential for colony-colony inhibition or of colony spreading (Trevors, 1998). In addition, plate growth favors those microorganisms with fast growth rates and those fungi that produce large numbers of spores (Dix and Webster, 1995). All of these limitations can influence the apparent diversity of the microbial community.

Oliveira and Pampulha (2006) reported marked decrease in total culturable bacterial population as well as those of asymbiotic $\mathrm{N}$-fixing bacteria in As contaminated soil. Similar effects on heterotrophic and diazotrophic populations were observed by Keeling and Cater (1998) in $\mathrm{Cu}, \mathrm{Pb}$ and $\mathrm{Zn}$ contaminated soils. 
Moriera et al. (2008) likewise reported decrease in populations of associative diazotrophs from $\mathrm{Cd}$ and $\mathrm{Zn}$ contaminated soils when evaluated using a number of $\mathrm{N}$-free media. Such negative correlation was noted particularly between populations of Rhizobium and cyanobacteria and concentrations of $\mathrm{Cu}$ and $\mathrm{Zn}$ in soils treated with metal-spiked sludge (Horsewell et al., 2008).

After comparative assessment of culture-dependent and culture-independent methods for studying metal contamination effects on soil diversity, Ellis et al. (2003) suggested that plate count is a more appropriate method. This was based on their findings that metal contamination did not have a significant effect on total genetic diversity but affected physiological status, so that the selectivity of culture methods towards more dominant physiologically active populations may be more appropriate indicators of soil quality. This is also congruent with the findings made by Lawlor et al. (2000).

\section{Community level physiological profile (CLPP) of} metal contaminated soils Determination of the range of $\mathrm{C}$ substrates, which the microorganisms are capable of using offers a method of characterizing the functional diversity of the microbial community. The microbial utilization of C-substrates has also been recommended as a biological indicator of heavy metal stress. The assay for this was based on the Biolog system where the soil suspension from source is inoculated into wells of a microtiter plate (Smalla et al., 1998). Each well contains a different $\mathrm{C}$ source, nutrients, and a tetrazolium dye. The rate of color development in wells provides information about density and/or metabolic activity of bacterial cells in an inoculum, while the diversity of color development in wells about microbial diversity in soil solution (Stefanowicz, 2006). The characteristic pattern obtained this way is called "metabolic fingerprint" or "community-level physiological profile (CLPP)".

Studies done using the Biolog method on reclaimed mining wastelands in China showed that microbial communities from the heavy metal polluted soil increased their utilization of D-fructose, D-glucose, D-trehalose, and D-melibiose, and lower utilization of D-lactose, L-serine, and D-psicose (Liao and Xie, 2007). Although it is often assumed that the difference in average $\mathrm{C}$ utilization could be explained partly by lower biomass and activity, Yao et al. (2003) found that C utilization values in the Biolog plates were not correlated with microbial biomass or heavy metal concentrations. The lowest value, however, occurred in the most polluted soil after 4 days of incubation. The researchers proposed that derived average well color development (AWCD) values provided information on differences in community structure but this may not clearly relate to microbial biomass. On the contrary, Muhammad et al. (2005) showed that AWCD values in the Biolog plates were closely related to the soil microbial biomass and heavy metal concentrations. Addition of $\mathrm{Pb}$ and $\mathrm{Cd}$ inhibited the functional activity of soil microbial communities as indicated by the intensity of AWCD during $168 \mathrm{~h}$ of incubation. They demonstrated by multivariate analysis that higher levels of metal application significantly affected soil microbial community structure.

Fatty acid methyl ester (FAME) analysis This is a biochemical method that does not rely on culturing of microorganisms. This method provides information on the microbial community composition based on groupings of fatty acids (Ibekwe and Kennedy, 1998). Fatty acids make up a relatively constant proportion of the cell biomass and signature fatty acids exist that can be used for differentiating major taxonomic groups within a community. Therefore, a change in the fatty acid profile would represent a change in the microbial population. This method detects changes in the composition of the bacterial and/or fungal community, as well as enables one to follow signature fatty acids of different groups of microorganisms.

Using this technique for analysis of microbial phospholipid-linked fatty acid (PLFA) and ester-linked fatty acid (ELFA), Hinojosa et al. (2005) noted that the microbial stress marker, monounsaturated fatty acids, was significantly lower for reclaimed and metal polluted soil over non-polluted soils for both PLFA and ELFA extraction. Another stress marker, the monounsaturated to saturated fatty acids ratio, only showed this for the PLFA. The general fungal marker (18:2 $\omega 6 \mathrm{c})$, the arbuscular mycorrhizae marker $(16: 1 \omega 5 \mathrm{c})$, and iso- and anteiso-branched PLFAs (gram positive bacteria) were suppressed with increasing pollution, whereas 17:0cy (gram negative bacteria) increased with metal pollution. Decrease in fungi population as indicated by fatty 
acid assay was also noted in metal-containing sewage

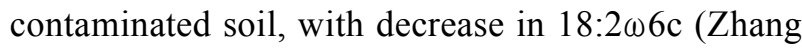
et al., 2008b). Kelly et al. (1999) likewise noted a significant decrease in the arbuscular mycorrhizae indicator along with the actinomycetes indicator, 16:0 Me in comparison to the control. However, they noted the opposite for 18:2w6c, which was significantly higher in $\mathrm{Zn}$-amended soils, along with two other actinomycete indicators, 18:10 Me and 17:10 Me. Baath et al. (1998) likewise noted the significant alteration in PLFA patterns in soils with higher levels of $\mathrm{Cu}, \mathrm{Ni}$ and $\mathrm{Zn}$ contamination.

Use of FAME however has many limitations. Cellular fatty acid composition can be influenced by factors such as temperature and nutrition, and the possibility exists that other organisms can confound the FAME profiles (Graham et al., 1998). In addition, individual fatty acids cannot be used to represent specific species because individuals can have numerous fatty acids and the same fatty acids can occur in more than one species (Bossio et al., 1998).

\section{Effects of Metals on Microbial Diversity based on Molecular-based Techniques}

\section{PCR-based techniques and 16S rDNA analysis}

Polymerase chain reaction overcomes the limitations of culture-based techniques and allows amplification of small amounts of DNA extracted from natural samples such as the soil (Roling and Head, 2005). PCR-based methods are often preferred because there is no need for large quantities of samples and are conducive to high throughput and comparative analysis (Nakatsu, 2007). The 16S rRNA gene has so far been the primary tool in environmental microbiology, including studying metal effects because of the enormous number of 16SrRNA gene sequences that have accumulated in public databases. The Ribosomal Database Project (RDP) now contains 243,909 aligned rRNA sequences (Cole et al., 2005; Zwolinski, 2007). In addition, the gene is present in all prokaryotes, the products show functional constancy, it is sufficiently long for documentation of evolutionary history and the gene shows very limited evidence for horizontal transfer (Rolling and Head, 2005). The DNA is amplified using universal primers, and the resulting products are separated in different ways. Some are describes below.
Denaturing gradient gel electrophoresis (DGGE) and Temperature gradient gel electrophoresis (TGGE) DGGE was the first DNA fingerprinting approach to be successfully applied to microbial ecology. DGGE and TGGE separation is based on the decreased electrophoretic mobility of a partially melted double stranded DNA molecule in polyacrylamide gels containing a linear gradient of DNA denaturants (a mixture of urea and formamide) or a linear temperature gradient (Muyzer and Smalla, 1998). The difference is that in DGGE, the chemical denaturant is the gradient while TGGE makes use of temperature (Liu et al., 2006).

This technique has been used extensively in the analysis of the impact of metal contamination to soil microbial population and diversity. Most of these studies showed decreasing number of DGGE bands with increasing levels of metal pollution, indicating altered microbial communities (Wang et al., 2007a; $\mathrm{Hu}$ et al., 2007; Khan et al., 2007). Inverse relationship between band patterns and concentrations of $\mathrm{Pb}$ and $\mathrm{Cd}$ in soils that were contaminated with mine tailings has been reported (Hu et al., 2007; Khan et al., 2007). Using this technique, similar finding was reported by Sobolev and Begonia (2008) at low concentration of $\mathrm{Pb}$, adding that the reduction was steady after radical increase in metal concentration from $0-2000 \mathrm{mg} \mathrm{kg}^{-1}$. Decrease in bacterial diversity was also reported from soils treated with $\mathrm{Cd}$ and Ni-rich sludge, however, the diversity increased with $\mathrm{Mn}$ and Zn-rich sludge treatment (Renella et al., 2005; Mench et al., 2006). Renella et al. (2005) suggested this as probably from the combined effect of the nutrient input and lack of metal toxicity. Ellis et al. (2003), however, did not see any difference in bacterial communities between metal contaminated and pristine soils using this molecular technique despite finding significantly different community profiles using culture dependent techniques. Linton et al. (2007) likewise reported no significant difference in the number of dominant species identified, although marked different in species composition was seen.

\section{Influence of Soil Parameters on Metal Toxicity to Microorganisms}

The most common way of assessing metal toxicity in the soil involves total metal levels. Existing guidelines and standards on heavy metals in soils are mostly 
based on total metal concentrations (Commission of the European Communities, 1986; CCME, 1999; Wang et al., 2007b). However, it is has been recognized now that total metal concentrations are poor indicators of the actual concentration in the soil solution that microorganisms interact with (Petänen and Romantschuk, 2002; Wang et al., 2007b; Giller et al., 2009). Variations and inconsistencies in the responses of the bioindicators discussed above as a result of metal contamination can be explained by differences in bioavailability of the metal to the microorganism. Besides this, soil is a complex system with large spatial variations so that routine soil measurements do not often reflect the availability of metals (Wang et al., 2007b). The type of soil affects the binding of the heavy metal ions, including soil $\mathrm{pH}$, soil matrix, climatic conditions, microbial activity and water flow (Haferburg and Kothe, 2007). In addition, cation exchange capacity (CEC), organic matter $(\mathrm{OM})$ content, quantity and type of clay minerals, the content of the oxides of $\mathrm{Fe}, \mathrm{Al}$ and $\mathrm{Mn}$, and the redox potential are all believed to determine the soil's ability to retain and immobilize heavy metals (Aydinalp and Marinova, 2003).

The CEC of soil is a measurement of its ability to bind or hold exchangeable cations. It is a measure of the number of negatively charged binding sites in the soil. Most heavy metals exist mainly as cations in the soil and their adsorption therefore, depends on the density of negative charges on the surface of the soil colloids. The CEC has been shown to play a very big role in metal concentration and bioavailability in soils (Giller et al., 2009; Smolders et al., 2004; Mansur and Garba, 2010). In general the higher is the CEC, the greater is the ability of soil to retain heavy metals. However, CEC is strongly dependent on the type and amount of OM, oxyhydroxides present in the soil, clay content and type, and soil $\mathrm{pH}$. Heavy metals tend to form complexes with organic matter in the soils, which varies for each metal. In addition to forming complexes, organic matter also retain them in exchangeable forms. Surface charge on $\mathrm{OM}$ and oxyhydroxides increases with $\mathrm{pH}$, thereby increasing their sorption capacity for metals (thus decreasing metal bioavailability). Conversely, positive surface charges increase as the $\mathrm{pH}$ drops, which increases sorption of anions (e.g., As or Se) under low $\mathrm{pH}$ conditions and decreasing sorption of cationic metals. The influence of clay is also in relation to its contribution to the CEC of the soil.

Soil reaction or the measure of acidity or alkalinity of soil also affects the mobility and speciation of metals. Many heavy metals become more water soluble under acid conditions. It was noted that each unit decrease in $\mathrm{pH}$ results to about 2-fold increase in the concentrations of metals, like $\mathrm{Zn}, \mathrm{Ni}$ and $\mathrm{Cd}$ in the soil solution (Christensen, 1984; Sanders et al., 1986; Giller et al., 1998). Moreover, its influence on the toxicity of metals in soil maybe more complex as it is likewise known to influence availability of nutrients, as well as microbial population and activity.

\section{Conclusion}

The assessment of the effects metals and metalloids on soil microbial communities is crucial in understanding the ramification of these pollutants to soil quality, productivity and safety. The techniques that have been used so far to assess these effects have been directed at analyzing changes in soil microbial functions (e.g. metabolic processes and enzymatic activities), community structure and diversity (biochemical, including culture-based and molecular techniques). As the review has shown, microbial parameters, like basal respiration, $\mathrm{C}$ mineralization and enzymatic activities, provide good indices of functional changes in the soil. While these are sensitive indicators, none however, is sufficient on its own and can be used universally. In most cases, indices for microbial functions are coupled with measurements of microbial populations. For such procedure, most researches have greatly relied on molecular techniques, such as the PCR-based methods for monitoring changes in microbial size and diversity. Molecular techniques confounded the limitations of culture-dependent techniques and can provide an assessment of the responses of a broader soil population. Changes in total genetic diversity in metal polluted soils however, may not be as significant as the effects on physiological status of the soil. For this reason, some studies still support the use of culture-dependent techniques, which tend to be selective towards physiologically dominant populations in the soil. A less utilized (at least in heavy metal effect studies) and relatively new procedure, the microarray technique, can perhaps address both limitations. Microarray makes use of gene probes to monitor the expression of thousands of different genes (e.g. 
metabolic, reproductive) under certain conditions, such as metal stress, without the need for cultivation. The recently introduced GeoChip 3.0, which works on the microarray principle promises to be an even more powerful and high throughput tool, which future studies on metal influences on soil microbial population, should find highly useful (He et al., 2010). In addition to selecting the appropriate techniques to better understand microbial responses to metals, is equally important also to determine both concentration and availability of heavy metal as well as the physical and chemical conditions that are prevalent in the soil (Wang et al., 2007b).

\section{Acknowledgement}

This work has been partially supported by the Rural Development Administration (RDA), Republic of Korea.

\section{References}

Adhikari, S. and S. Ayyappan. 2004. Behavioral role of zinc on primary productivity, plankton and growth of a freshwater teleost, Labeo rohita (Hamilton). Aquaculture 231:327-336.

Alef, K., P. Nannipieri, and C. Trasar Cepeda. 1995. Phosphatase activity. p. 335-344. In K. Alef and P. Nannipieri (ed.) Methods in Applied Soil Microbiology and Biochemistry. Academic Press, London.

Alloway, B.J. 1995. Heavy metals in soils. Blackie Academic and Professional, New York.

Almas, A.R., L.R. Bakken, and J. Mulder. 2004. Changes in tolerance of soil microbial communities in $\mathrm{Zn}$ and $\mathrm{Cd}$ contaminated soils. Soil Biol. Biochem. 36:805-813.

Anderson, J.P.E. 1982. Soil respiration. In A.L. Page, R.H. Miller, and D.R. Keeny (ed.) Methods of soil analysis. Part 2. Chemical and microbiological properties. Agronomy 9. American Society of Agronomy, Madison, WI.

Aydinalp, C. and S. Marinova. 2003. Distribution and forms of heavy metals in some agricultural soils. Pol. J. Environ. Stud. 12:629-633.

Baath, E., K. Arnebrant, and A. Nordgren. 1991. Microbial biomass and ATP in smelter-polluted forest humus. Bull. Environ. Contam. Toxicol. 47:278-282.

Baath, E., Montserrat, A. Diaz-Ravina, A. Frostegard, and C.D. Campbell. 1998. Effect of metal-rich sludge amendments on the soil microbial community. Appl. Environ. Microbiol. 64: 238-245.

Baker, B. and D. Tracy. 2008. Elemental contaminants in fertilizers and soil amendments used in organic production. Cultivating the future based on science: 2nd Conference of the International Society of Organic Agriculture Research
ISOFAR, Modena, Italy.

Bhattacharyya, P., S. Tripathy, K. Kim, and S. Kim. 2008. Arsenic fractions and enzyme activities in arsenic-contaminated soils by groundwater irrigation in West Bengal. Ecotox. Environ. Safe. 71:149-156.

Benavides, M.P., S.M. Gallego, and M.L. Tomaro. 2005. Cadmium toxicity in plants. Braz. J. Plant Physiol. 17:21-34.

Borneman, J. and E.W. Triplett. 1997. Molecular microbial diversity in soils from eastern Amazonia: Evidence for unusual microorganisms and microbial population shifts associated with deforestation. Appl. Environ. Microbiol. 63:2647-2653.

Bossio, D.A., K.M. Scow, N. Gunapala, and K.J. Graham. 1998. Determinants of soil microbial communities: effects of agricultural management, season, and soil type on phospholipid fatty acid profiles. Microb. Ecol. 36:1-12.

Brookes, P.C. 1995. The use of microbial parameters in monitoring soil pollution by heavy metals. Biol. Fert. Soils 19:269-279.

Broos, K., L.M. Macdonald, M.S.J. Warne, D.A. Heemsbergen, M.B. Barnes, M. Bell, and M.J. McLaughlin. 2007. Limitations of soil microbial biomass carbon as an indicator of soil pollution in the field. Soil Biol. Biochem. 39:2693-2695.

Bruins, M.R., S. Kapil, and F.W. Oehme. 2000. Microbial resistance to metals in the environment. Ecotox. Environ. Safe. 45:198-207.

CCME. 1999. Canadian soil quality guidelines for the protection of environmental and human health: Zinc. In Canadian environmental quality guidelines. Canadian Council of Ministers of the Environment, Winnipeg.

Chien, C., Y. Kuo, C. Chen, C. Hung, C. Yeh, and W. Yeh. 2008. Microbial diversity of soil bacteria in agricultural field contaminated with heavy metals. J. Environ. Sci. 20:359-363.

Christensen, T.H. 1984. Cadmium soil sorption at low concentrations. I. Effect of time, cadmium load, $\mathrm{pH}$ and calcium. Water Air Soil Pollut. 21:105-114.

Cole, J.R., B. Chai, R.J. Farris, Q. Wang, S.A. Kulam, D.M. McGarrell, G.M. Garrity, and J.M. Tiedje. 2005. The Ribosomal Database Project (RDP-II): Sequences and tools for highthroughput rRNA analysis. Nucleic Acids Res. 33: D294-D296.

Commission of the European Communities. 1986 Council Directive of 12 June 1986 on the protection of the environment, and in particular of the soil, when sewage sludge is used in agriculture. Official Journal of the European Communities L181 (86/278/EEC): 6-12.

Crowley, D. 2008. Impacts of metals and metalloids on soil microbial diversity and ecosystem function. 5th International Symposium ISMOM, Pucón, Chile.

Dahlin, S., E. Witter, A. Martenson, A. Turner, and E. Baath. 1997. Where's the limit? Changes in the microbiological properties of agricultural soils at low levels of metal contamination. Soil Biol. Biochem. 29:1405-1415.

Dai, J., T. Becquer, J. Rouiller, G. Reversat, F. Bernhard-Reversat, and P. Lavelle. 2004. Influence of heavy metals on $\mathrm{C}$ and $\mathrm{N}$ mineralisation and microbial biomass in $\mathrm{Zn}-, \mathrm{Pb}-, \mathrm{Cu}-$, and Cd-contaminated soils. Appl. Soil Ecol. 25:99-109.

Dick, W.A. and M.A. Tabatabai. 1983. Effects of soils on acid 
phosphatase and inorganic pyrophosphatase of corn roots. Soil Sci. 136:19-25.

Dix, N.J. and J. Webster. 1995. Fungal ecology. Chapman \& Hall, London.

Edvantoro, B.B., R. Naidu, M. Megharaj, and I. Singleton. 2003. Changes in microbial properties associated with long-term arsenic and DDT contaminated soils at disused cattle dip sites. Ecotox. Environ. Safe. 55:344-351.

Ellis, R.J., P. Morgan, A.J. Weightman, and J.C. Fry. 2003. Cultivation-dependent and -independent approaches for determining bacterial diversity in heavy metal contaminated soil. Appl. Environ. Microbiol. 69:3223-3230.

Eivazi, F. and M.A. Tabatabai. 1990. Factors affecting glucosidase and galactosidase activities in soils. Soil Biol. Biochem. 22: 891-897.

Ewers, U. and H.W. Schlipköter. 1990. Lead. In E. Merian (ed.) Metals and their compounds in the environment. Wiley$\mathrm{VCH}$, Weinheim.

Fliessbach, A., R. Martens, and H.H. Reber. 1994. Soil microbial biomass and microbial activity in soils treated with heavy metal contaminated sewage sludge. Soil Biol. Biochem. 26: 1201-1205.

Ghosh, A.K., P. Bhattacharyya, and R. Pal. 2004. Effect of arsenic contamination on microbial biomass and its activities in arsenic contaminated soils of Gangetic West Bengal, India. Environ. Int. 30:491-499.

Giller, K.E., E. Witter, and S.P. McGrath. 2009. Heavy metals and soil microbes. Soil Biol. Biochem. 41:2031-2037.

Giller, K.E., E. Witter, and S.P. McGrath. 1998. Toxicity of heavy metals to microorganisms and microbial processes in agricultural soils: A review. Soil Biol. Biochem. 30:1389-1414.

Graham, J.H., N.C. Hodge, and J.B. Morton. 1998. Fatty acid methyl ester profiles for characterization of glomalean fungi and their endomycorrhizae. Appl. Environ. Microbiol. 61:58-64.

Grundmann, G.L. and F. Gourbière. 1999. A micro-sampling approach to improve the inventory of bacterial diversity in soil. Appl. Soil Ecol. 387:1-4.

Haferburg, G. and E. Kothe. 2007. Microbes and metals: interactions in the environment. J. Basic Microbiol. 47:453-467.

Hattori, T., H. Mitsui, H. Haga, N. Wakao, S. Shikano, K. Gorlach, Y. Kasahara, A. El-Beltagy, and R. Hattori. 1997. Advances in soil microbial ecology and the biodiversity. Antonie van Leeuwenhoek 72:21-28.

He, Z., Y. Deng, J.D. Van Nostrand, Q. Tu, M. Xu, C.L. Hemme, X. Li, L. Wu, T.J. Gentry, Y. Yin, J. Liebich, T.C. Hazen, and J. Zhou. 2010. GeoChip 3.0 as a highthroughput tool for analyzing microbial community composition, structure and functional activity. ISME J. 4:1167-79.

Hinojosa, M.B., J.A. Carreira, R. Garcia-Ruız, and R.P. Dick. 2005. Microbial response to heavy metal-polluted soils: community analysis from phospholipids-linked fatty acids and ester-linked fatty acids extracts. J. Environ. Qual. 34:1789-1800.

Hu, Q., H. Qi, J. Zeng, and H. Zhang. 2007. Bacterial diversity in soils around a lead and zinc mine. J. Environ. Sci. 19:74-79.

Horsewell, J., T.W. Spier, A.P. van Schaik, L.C. Hunter, H.J. Percival, R.G. Mclaren, and L. Clucas. 2008. Impacts of heavy metals from land-applied $\mathrm{Cu}-$, Ni-, and $\mathrm{Zn}$-spiked sewage sludge on nitrogen fixing rhizobia. In G.H. Couto (ed.) Nitrogen fixation research progress. Nova Science Pub. Inc., New York.

Ibekwe, A.M. and A.C. Kennedy. 1998. Phospholipid fatty acid profiles and carbon utilization patterns for analysis of microbial community structure under field and greenhouse conditions. FEMS Microbiol. Ecol. 26:151-163.

Insam, H., T.C. Hutchinson, and H.H. Reber. 1996. Effects of heavy metal stress on the metabolic quotient of the soil microflora. Soil Biol. Biochem. 28:691-694.

Islam, S.M.A., K. Fukushi, and K. Yamamoto. 2006. Contamination of agricultural soil by arsenic containing irrigation water in Bangladesh: overview of status and a proposal for novel biological remediation. In A.G. Kungolos (ed.) Environmental toxicology. Wessex Institute of Technology, UK.

Kakhki, F.V., G. Haghnia, and A. Lakzian. 2008. Effect of enriched sewage sludge on soil urease activity. Soil Environ. 27:143-147.

Kanazawa, S. and K. Mori. 1996. Isolation of cadmium-resistant bacteria and their resistance mechanisms. Soil Sci. Plant Nutr. 42:425-430.

Kao, P., C. Huang, and Z. Hseu. 2006. Response of microbial activities to heavy metals in a neutral loamy soil treated with biosolid. Chemosphere 64:63-70.

Keeling, A.A. and G. Cater. 1998. Toxicity of copper, lead, nickel and zinc in agar culture to aerobic, diazotrophic bacteria extracted from waste-derived compost. Chemosphere 37:1073-1077.

Kelly, J.J., M. Haggblom, and R.L. Tate III. 1999. Changes in soil microbial communities over time resulting from one time application of zinc: a laboratory microcosm study. Soil Biol. Biochem. 31:1455-1465.

Kersten, M. 1988. Geochemistry of priority pollutants in anoxic sludges: Cadmium, arsenic, methyl mercury, and chlorinated organics. p. 170-213. In W. Salomons and U. Forstner (ed.) Chemistry and biology of solid waste. Springer-Verlag, Berlin.

Khan, S., Q. Cao, A.E. Hesham, Y. Xia, and J. He. 2007. Soil enzymatic activities and microbial community structure with different application rates of $\mathrm{Cd}$ and $\mathrm{Pb}$. J. Environ. Sci. 19:834-840.

Kirk, J.L., L.A. Beaudette, M. Hart, P. Moutoglis, J.N. Klironomos, H. Lee, and J.T. Trevors. 2004. Methods of studying soil microbial diversity. J. Microbiol. Meth. 58: 169-188.

Kızılkaya, R., T. Askın, B. Bayraklı, and M. Saglam. 2004. Microbiological characteristics of soils contaminated with heavy metals. Eur. J. Soil Biol. 40:95-102.

Kuperman, R.G. and M.M. Carreiro. 1997. Soil heavy metal concentrations, microbial biomass and enzyme activities in a contaminated grassland ecosystem. Soil Biol. Biochem. 29: 179-190.

Lacatusu R., L. Anca-Rovena, L. Mihaela, and B.J. Gabriela. 2008. Macro and microelements abundance in some urban soil from Romania. Carpathian J. Earth Environ. Sci. 3:75-83.

Lawlor, K, B.P. Knight, V.L. Barbosa-Jefferson, P.W. Lane, 
A.K. Lilley, G.I. Paton, S.P. McGrath, S.M. O'laherty, and P.R. Hirsch. 2000. Comparison of methods to investigate microbial populations in soils under different agricultural management. FEMS Microbiol. Ecol. 33:129-37.

Liao, M., C.L. Chen, L.S. Zeng, and C.Y. Huang. 2007. Influence of lead acetate on soil microbial biomass and community structure in two different soils with the growth of Chinese cabbage (Brassica chinensis). Chemosphere 66: 1197-1205.

Liao, M. and X.M. Xie. 2007. Effect of heavy metals on substrate utilization pattern, biomass, and activity of microbial communities in a reclaimed mining wasteland of red soil area. Ecotox. Environ. Safe. 66:217-223.

Linton, P.E., L. Shotbolt, and A.D. Thomas. 2007. Microbial communities in long-term heavy metal contaminated ombrotrophic peats. Water Air Soil Pollut. 186:97-113.

Liu, B., G. Jia, J. Chen, and G. Wang. 2006. A review of methods for studying microbial diversity in soils. Pedosphere 16:18-24.

Liu, S., Z. Yang, X. Wang, X. Zhang, R. Gao, and X. Liu. 2007. Effects of $\mathrm{Cd}$ and $\mathrm{Pb}$ pollution on soil enzymatic activities and soil microbiota. Frontiers Agric. China 1:85-89.

Mansur, U.D. and K.A. Garba. 2010. Effects of some heavy metal pollutants on fertility characteristics of an irrigated savannah alfisol. Bayero J. Pure Appl. Sci. 3:255-259.

Magnani, D. and M. Solioz. 2007. How bacteria handle copper. p. 259-285. In D.H. Nies and S. Silver (ed.) Bacterial transition metal homeostasis. Springer, Heidelberg, Germany.

Majer, B.J., D. Tscherko, and A. Paschke. 2002. Effects of heavy metal contamination of soils on micronucleus induction in Tradescantia and on microbial enzyme activities: a comparative investigation. Mutat. Res. 515:111-124.

Martínez-Iñigo, M.J., A. Pérez-Sanz, I. Ortiz, J. Alonso, R. Alarcón, P. García, and M.C. Lobo. 2009. Bulk soil and rhizosphere bacterial community PCR-DGGE profiles and b-galactosidase activity as indicators of biological quality in soils contaminated by heavy metals and cultivated with Silene vulgaris (Moench) Gracke. Chemosphere 75:1376-1381.

McGrath, S.P., B. Knight, K. Killham, S. Preston, and G.I. Paton. 1999. Assessment of the toxicity of metals in soils amended with sewage sludge using a chemical speciation technique and a lux-based biosensor. Environ. Toxicol. Chem. 18:659-663.

Mench, M., G. Renella, A. Gelsomino, L. Landi, and P. Nannipieri. 2006. Biochemical parameters and bacterial species richness in soils contaminated by sludge-borne metals and remediated with inorganic soil amendments. Environ. Pollut. 144:24-31.

Mikanova, O. 2006. Effects of heavy metals on some soil biological parameters. J. Geochem. Explor. 88:220-223.

Moreira, F.M.S., A. Lange, O. Klauberg- Filho, J.O. Siqueira, R.S.A. Nobrega, and A.S. Lima. 2008. Associative diazotrophic bacteria in grass roots and soils from heavy metal contaminated sites. Anais da Academia Brasileiara de Ceincias 80:749-761.

Muhammad, A., J. Xu, Z. Li, H. Wang, and H. Yao. 2005. Effects of lead and cadmium nitrate on biomass and substrate utilization pattern of soil microbial communities. Chemosphere
60:508-514.

Muyzer, G. and K. Smalla. 1998. Application of denaturing gel electrophoresis (DGGE) and temperature gradient gel electrophoresis in microbial ecology. Antonie van Leeuwenhoek 73:127-141.

Nakatsu, C.H. 2007. Soil microbial community analysis using dentauring gel electrophoresis. Soil Sci. Soc. Am. J. 71:562-571.

Nicholson, F.A., S.R. Smith, B.J. Alloway, C. Carlton-Smith, and B.J. Chambers. 2003. An inventory of heavy metal inputs to agricultural soils in England and Wales. Sci. Total Environ. 311:205-219.

Oliveira, A. and M.E. Pampulha. 2006. Effects of long-term heavy metal contamination on soil microbial characteristics. J. Biosci. Engin. 102:157-161.

Ortiz, O. and J.P. Alcaniz. 1993. Respiration potential of microbial biomass in a calcareous soil treated with sewage sludge. Geomicrobiol. J. 11:333-340.

Pace, N.R. 1997. A molecular view of microbial diversity and the biosphere. Science 276:734-740.

Patra, M. and A. Sharma. 2000. Mercury toxicity in plants. Bot. Rev. 66:379-409.

Petänen, T. and M. Romantschuk. 2002. Use of bioluminescent bacterial sensors as an alternative method for measuring heavy metals in soil extracts. Anal. Chim. Acta 456:55-61.

Qishlaqi, A., F. Moore, and G. Forghani. 2008. Impact of untreated wastewater irrigation on soils and crops in Shiraz suburban area, SW Iran. Environ. Monit. Assess. 141:257-73.

Renella, G., M. Mench, A. Gelsominoc, L. Landia, and P. Nannipieri. 2005. Functional activity and microbial community structure in soils amended with bimetallic sludges. Soil Biol. Biochem. 37:1498-1506.

Rolling W.F.M. and L.M. Head. 2005. Prokaryotic systematics: PCR and sequence analysis of amplified 16s rRNA genes. p. 25-64. In A.M. Osborn and C.J. Smith (ed.) Molecular microbial ecology. Taylor and Francis, New York.

Sanders, J.R., S.P. McGrath, and T.M. Adams. 1986. Zinc, copper and nickel concentrations in ryegrass grown on sludge contaminated soils of different pH. J. Sci. Food Agric. 37:961-968.

Shorrocks, V.M. and B.J. Alloway. 1985. Copper in plant, animal and human nutrition. Copper Development Association, Potters Bar, Hertfordshire.

Smalla, K., U. Wachtendorf, H. Heuer, W.T. Liu, and L. Forney. 1998. Analysis of BIOLOG GN substrate utilization patterns by microbial communities. Appl. Environ. Microbiol. 64:1220-1225

Smolders, E., J. Buekers, I. Oliver, and M.J. McLaughlin. 2004. Soil properties affecting toxicity of $\mathrm{Zn}$ to soil microbial properties in laboratory-spiked and field-contaminated soils. Environ. Toxicol. Chem. 23:2633-2640.

Sobolev, D. and M.F.T. Begonia. 2008. Effects of heavy metal contamination upon soil microbes: lead-induced changes in general and denitrifying microbial communities as evidenced by molecular markers. Int. J. Environ. Res. Public Health 5:450-456.

Stefanowicz, A. 2006. The Biolog plates technique as a tool in 
ecological studies of microbial communities. Polish J. Environ. Stud. 15:669-676.

Stępniewska, Z., A.Wolinska, and J. Ziomek. 2009. Response of soil catalase activity to chromium contamination. J. Environ. Sci. 21:1142-1147.

Tabacchioni, S., L. Chiaini, A. Bevivino, C. Cantale, and C. Dalmastri. 2000. Bias caused by using different isolation media for assessing the genetic diversity of a natural microbial population. Microb. Ecol. 40:169-176.

Torsvik, V., F.L. Daae, R.A. Sandaa, and L. Oslash;vreás. 1998. Novel techniques for analyzing microbial diversity in natural and perturbed environments. J. Biotechnol. 64:53-62.

Trevors, J.T. 1998. Bacterial biodiversity in soil with an emphasis on chemically contaminated soils. Water Air Soil Pollut. 101:45-67.

Vasquez-Murrieta, M.S., I. Migueles-Garduño, O. Franco-Hernández, B. Govaerts, and L. Dendooven. 2006. C and N mineralization and microbial biomass in heavy metal contaminated soil. Eur. J. Soil Biol. 42:89-98.

Vig, K., M. Megharaj, N. Sethunathan, and R. Naidu. 2003. Bioavailability and toxicity of cadmium to microorganisms and their activities in soil: a review. Adv. Environ. Res. 8:121-135.

Wang, Y., J. Shi, H. Wang, Q. Lin, X. Chen, and Y. Chen. 2007a. The influence of soil heavy metals pollution on soil microbial biomass, enzyme activity, and community composition near a copper smelter. Ecotox. Environ. Safe. 67:75-81.

Wang, Y., J. Shi, H. Wang, Q. Lin, X. Chen, and Y. Chen. 2007b. Heavy metal availability and impact on activity of soil microorganims along a $\mathrm{Cu} / \mathrm{Zn}$ contamination gradient. J. Environ. Sci. 19:848-853.
Wang, F., J. Yao, Y. Si, H. Chen, M. Russel, K. Chen, Y. Qian, G. Zaray, and E. Bramanti. 2010. Short-time effect of heavy metals upon microbial community activity. J. Hazard. Mater. 173:510-516.

Wardle, D.A. and A. Ghani. 1995. A critique of the microbial metabolic quotient $\left(q \mathrm{CO}_{2}\right)$ as a bioindicator of disturbance and ecosystem development. Soil Biol. Biochem. 27:1601-1610.

Yao, H., J. Xu, and C. Huang. 2003. Substrate utilization pattern, biomass and activity of microbial communities in a sequence of heavy metal-polluted paddy soils. Geoderma 115:139-148.

Yoshida, Y., S. Furuta, and E. Niki. 1993. Effects of metal chelating agents on the oxidation of lipids induced by copper and iron. Biochim. Biophys. Acta 1210:81-88.

Zeng, L.S., M. Liao, C.L. Chen, and C.Y. Huang. 2007. Effects of lead contamination on soil enzymatic activities, microbial biomass, and rice physiological indices in soil-leadrice (Oryza sativa L.) system. Ecotox. Environ. Safe. 67:67-74.

Zhang, Y., H. Zhang, Z. Su, and C. Zhang. 2008a. Soil microbial characteristics under long-term heavy metal stress: a case study in Zhangshi wastewater irrigation area, Shenyang. Pedosphere 18:1-10.

Zhang, Y.L., J.L. Dai, R.Q. Wang, and J. Zhang. 2008 b. Effects of long-term sewage irrigation on agricultural soil microbial structural and functional characterizations in Shandong. China. Eur. J. Soil Biol. 44:84-91.

Zheng, C.R., C. Tu, and H.M. Chen. 1999. Effect of combined heavy metal pollution on nitrogen mineralization potential, urease and phosphatase activities in a Typic Udic Ferrisol. Pedosphere 9:251-258.

Zwolinski, M.D. 2007. DNA sequencing: strategies for soil microbiology. Soil Sci. Soc. Am. J. 71:592-600. 